\title{
THE EFFECT OF PROBIOTIC ON IMMUNITY IMPROVEMENT IN THE FRY AND SPAWNER PRODUCTION OF PACIFIC WHITE SHRIMP Litopenaeus vannamei
}

\author{
Haryanti\#, Ahmad Muzaki, Sari Budi Moria Sembiring, Fahrudin, \\ I Gusti Ngurah Permana, and Ida Komang Wardana \\ Research and Development Institute for Mariculture, Gondol, Bali \\ (Received 17 June 2014; Final revised 28 October 2014; \\ Accepted 10 November 2014)
}

\begin{abstract}
In order to improve immune system of Pacific white shrimp L. vannamei from any kinds of diseases, various probiotic agents were tested such as Bacillus sp. BC, Alteromonas sp. BY-9 and mixed of both. The probiotics were cultured and added directly to the larval rearing tank $\left(10^{6} \mathrm{cfu} / \mathrm{mL}\right.$ equal to $\left.0.5 \mathrm{liter} / \mathrm{m}^{3}\right)$ up to PL-12. In cultured shrimp spawners, probiotic was mixed with feed coated with chitosan, and without adding probiotic as control. In the present experiment, shrimp fry and spawners were reared in tank capacity of $5 \mathrm{~m}^{3}$ and $8 \mathrm{~m}^{3}$. Immunity response was analyzed by quantitative value of the immunity related gene expression with RTqPCR. The results showed that survival rate of shrimp fry cultured with mixed probiotic was $63.16 \%$ (PL-8) and 53.46\% (PL-12), while control 13.35\% (PL-8) and 12.48\% (PL-12) respectively. The number of shrimp hemocytes starting from 420 to $530.5 \times 10^{4}$ cells/ $\mathrm{mL}$ and after challenged with WSSV (for $72 \mathrm{hrs}$ exposure) between two treatments of Alteromonas sp. BY-9 and Bacillus cereus BC was not significantly different $\mathrm{P}>0.05$ (402.5 and $432.5 \times 10^{4}$ cells $/ \mathrm{mL}$ ), while in mixed probiotic and control treatments were 391.75 and $229.0 \times 10^{4}$ cells $/ \mathrm{mL}$, respectively. The analysis of immunity gene expression revealed that the use of probiotic from larval stages up to spawner has been proved in increasing immunity responses quantified from ProPO activating system (prophenoloxidase/proPO) as much as 1.6-2.0 fold, clotting system (transglutaminase, clotting protein) of 1.5-2 fold, Antimicrobial Peptide System (antiLPS factor, crustin, lysozyme, penaiedin2) of 1.5-2.8 fold, and Antioxidant defense mechanism (superoxidase dismutase/SOD, glutathione peroxidase/GPx) of 1.8-2.0 fold compared to control.
\end{abstract}

KEYWORDS: fry, spawner, L. vannamei, probiotic, expression immunerelated gene

\section{INTRODUCTION}

Shrimp culture is one of important economic activities in Indonesia and very strategic for global market. Since the first introduction of L. vannamei in 2001 , this shrimp has been dominating the cultures. The production of $L$. vannamei in Indonesia was continuously increased from 244.650 tons in 2009 to 415.517 tons in 2012 (Marine and Fisheries Statistic, 2012).

The business of shrimp fry production and cultivation has been widely distributed and

\# Corresponding author. Research and Development Institute for Mariculture, Jl. Br. Gondol, Kec. Gerokgak, Kab. Buleleng, Kotak Pos 140, Singaraja, Bali 81101 , Indonesia. Tel.: +62 36292278 E-mail: haryanti@indosat.net.id 
successfully resulted in L. vannamei become a novel species in cultivation until now. However, global shrimp production has been hampered by diseases which impacts on economic failure. Viruses, bacteria, and fungus were the etiological agents of infectious diseases which often cause mass mortality in fry production and cultivated shrimp. The susceptibility to microbial infection has a close relationship with immune competence and the ability to avoid microorganism (Jimenez-Vega et al., 2004). Shrimp cultivation would be no longer successful since environmental problems i.e. WSSV, TSV, IHHNV, and IMNV have not solved yet. Some efforts have been made to avoid the incidence of contagious disease. The strategy for controlling infectious diseases has been done including improved environment management, at use of shrimp fry that allow SPF (Specific Pathogen Free) and SPR (Specific Pathogen Resistant) together with improvement of fry health against disease by using probiotic. In the frame of self-sustainability of Pacific shrimp L. vananmei cultivation, the efforts such as rehabilitation, anticipation, and prevention to the factors that cause failure have to be done continuously. One of the efforts with high attention is handling the health of L. vananmei shrimp. Improvement of shrimp health through application of probiotic probably more effective compared to vaccination. This method relates to immunity response system of shrimp which is differ to the fish. Shrimp has no immunity adaptive response with immunoglobulin (Lee \& Soderhall, 2002). Health improvement through addition of probiotic was done to explore the possible protective effect from fry stage up to shrimp spawner of $L$. vannamei against infection. One function of the probiotic is to stimulate immunity non specific mechanism and to protect the shrimp from the pathogenic infection.

Li et al. (2009), Zokaeifar et al. (2012), and Karla et al. (2011) stated that the use of probiotic could improve the growth performance, digestion enzyme, disease resistance, immune gene expession and reducing infection prevalence of WSSV and IHHNV on Pacific shrimp, $L$. vannamei. In the production of L. vannamei larvae the use of Bacillus subtilis E-20 which was isolated from fermented soya (natto) could improve the survival rate of $80 \%$, stadium development, tolerance to environmental stress and immune status (Liu et al., 2010; Tseng et al., 2009).
The protective and advantage impact of probiotic are considered as immunostimulan (Gullian et al., 2004). Various of feed supplements and additive stuff have been widely reported to avoid the infection disease (WSSV) in larval stage, juvenile, and maintenance in pond as well as to maintain water quality (Fu et al., 2011 ; Rodriguez et al., 2007; Zhou et al., 2009; Balcazar et al., 2007; Luis-Villasenor et al., 2011).

The use of probiotic on fry and spawner production is expected to improve immunity response of $L$. vannamei shrimp. An effort in health improvement of fry and spawner of $L$. vannamei is important in shrimp culture.

\section{MATERIALS AND METHODS}

\section{Probiotic Characterization and Culture}

\section{Probiotic Characterization (Bacillus sp. BC)}

The effort have been done in characterization of Bacillus, sequence of activities were isolation of bacteria from intestine of shrimp ( $P$. monodon) then cultured using Marine Agar. Bacteria colony was then purified to obtain pure bacteria for vibriostatic activity test (the ability to prohibit pathogenic bacteria, Vibrio harveyi). Vibriostatic test was done by wiping bacteria strain candidate ( $3 \mathrm{~cm}$ distance) and in the middle wiped the $V$. harveyi $(1.5 \mathrm{~cm}$ distance from two wiped bacteria strain candidate). The bacteria strain candidate which posses the ability to prevent the growth of pathogenic bacteria was then cultured and characterized for further test.

The bacteria that were obtained, was then analyzed and characterized molecularly at DNA level. Bacteria strain analysis as a result of purification was carried out by culturing in test tube of $10 \mathrm{~mL}$ culture volume. The bacteria strains were incubated for $48 \mathrm{hrs}$ at $25^{\circ} \mathrm{C}$. Cultured media used was Marine Broth sterilized by autoclave at $121^{\circ} \mathrm{C}$ for 15 minutes. The grown bacteria strain was centrifuged at 13,000 rpm for five minutes and then extracted for DNA genome followed the extraction method developed by Haryanti et al. (2001). DNA genome was amplified with 16Sr-DNA sequence using the primer pair of $27 f$ ( 5 '-AGA GTT TGA TC (AC) TGG CTC AG-3') and 1492r (5'- ACGG (CT) TAC CTT GTT ACG ACT T-3') and region target of 1,400 bp. Thermal cycle used for DNA template amplification i.e. denaturizing tem- 
perature at $95^{\circ} \mathrm{C}$ for one minute, annealing at $60^{\circ} \mathrm{C}$ for one minute and thermal extension at $72^{\circ} \mathrm{C}$ for three minutes. This cycle was repeated for 35 times. The amplification result was shown by separation through $1.5 \%$ agarose gel electrophoresis in 1xTBE buffer.

The DNA amplicon was purified with QIA Quick PCR purification (Qiagen) and sequenced by sequencer machine. The nucleotide structure (sequence) obtained was alliged with BLAST and homologized with the sequence of nucleotide in Gene Bank for Genus and Species identification of probiotic bacteria candidate. Based on this method it was identified that bacteria was Bacillus.

Alteromonas sp. BY-9 is the probiotic bacteria that has been used for culturing $P$. monodon larvae. It had been patented with Registration Number of P 0020010038 on 22 January 2001 with Publication Number 033.053 A.

\section{Probiotic Culture (Alteromonas sp. BY-9 and Bacillus sp. BC)}

Cultured method of probiotic followed the method developed by Haryanti et al. (2001) and Haryanti et al. (2003). Bacteria Alteromonas sp. BY-9 strain was cultured with nutria bacto peptone, bacto malt extract, bacto yeast extract, and bacto soytone in the portion of each $0.05 \%$; $0.1 \%$; $0.05 \%$; $0.1 \%$ in sterile sea water, $\mathrm{pH}$ 7.6. During incubation time for 48 hours, aeration was added through $0.20 \mu \mathrm{m}$ filter. $\mathrm{Ba}$ cillus sp. BC was grown in $0.5 \%$ bacto Pepton, $0.3 \%$ bacto Soytone, and $0.1 \%$ Yeast extract. Cell density obtained was around $10^{9-10} \mathrm{cfu} /$ $\mathrm{mL}$. In a small scale, media culture was sterilized by autoclave at $121^{\circ} \mathrm{C}$ for 15 minute. In a big scale $(20 \mathrm{~L})$ water media was sterilized by the addition of chlorine ( $25 \mathrm{mg} / \mathrm{L})$ and keep for 24 hours. Nutria has to be sterilized by autoclave at $121^{\circ} \mathrm{C}$ for 15 minutes previously before used for culture.

\section{L. vannamei Fry Production}

The experiment was carried out in two stages, the production of fry and spawner of $L$. vannamei shrimp.

At L. vannamei shrimp fry production stage, four treatments of probiotic was used to increase the survival rate, growth, and fry health. The probiotic was used i.e. Alteromonas sp. BY-9, Bacillus cereus BC, combination of Alteromonas sp. BY-9 and Bacillus sp. BC and control (without probiotic). Alteromonas sp. BY-9 is the probiotic bacteria that has been used for culturing P. monodon larvae. Another probiotic is a new isolate that still under investigation. Probiotic such as Alteromonas sp. BY9, Bacillus sp. BC and its combination were added every day on the larval rearing water of L. vannamei as much as $10^{5} \mathrm{cfu} / \mathrm{mL}( \pm 0,5 \mathrm{~L} /$ $\left.\mathrm{m}^{3}\right)$. The larval rearing of $L$. vannamei were continued up to Post Larvae (PL)-12. Before rearing L. vannamei larvae, health diagnose of nauplii were held according to SPF (Specific Pathogen Free) condition. The test was done to identify the presence infection of virus such as TSV, WSSV, IHHNV, IMNV, YHV, BP, MBV, and HPV. The test results have to be negative for all virus. The specific primers were used with speedy $P C R$ for virus detection. Larvae were cultured in tank of $5 \mathrm{~m}^{3}$ volume with three replications. In this activity, shrimp larvae were reared by giving natural feeds, i.e. Chaetoceros ceratosporum, Thallasiosira sp., Skeletonema sp., Artemia sp., and micro artificial died. Feeding was done 3-4 times a day. Initial density of C. ceratosporum in early larval stage (zoea) were 10,000-30,000 cells $/ \mathrm{mL}$; while in the next stage (mysis) it were fed Thallasiosira sp. and Skeletonema sp. at density of 25,000-35,000 cell/mL and Artemia sp. (5-15 nauplii Artemia) post larva). The rearing water was begun to change in zoea-3 until post larva (PL) stages in various levels (15\%-50\%). Shrimp larvae were reared up to PL-12 and observed daily regarding their health and microflora performance as well as their survival. During carried out experiment biosecurity was applied strickly.

\section{Cultured of Pacific White Shrimp $L$. vannamei Spawner}

For spawner production, L. vannamei shrimps were reared from PL-12 onward up to spawner size $(35 \mathrm{~g})$. During rearing periods the shrimp were fed artificial diet mixed with Alteromonas sp. BY-9, Bacillus sp. BC, combination of both Alteromonas sp. BY-9 and Bacillus sp. BC probiotics and control (without probiotic). Each probiotic was cultured in a 1-2 $\mathrm{L}\left(10^{9} \mathrm{cfu} / \mathrm{mL}\right)$ volume and mixed into pellet feed $\left(100 \mathrm{~mL} / \mathrm{kg}\right.$ feed equal to $\left.10^{5} \mathrm{cfu} / \mathrm{mL}\right)$ and coated with chitosan. For control treatment, feed only was added with chitosan.

During the experiments, L. vannamei shrimp were reared in a round tank of $8 \mathrm{~m}^{3} \mathrm{ca}$ pacity with flow through system. Initial density of L. vannamei was 2,000 juveniles/tank and selected the size was done in every three 
months regularly. The bigger size were continued to be rearing, while small size were discarded. The shrimp were fed three times a day at a ratio of $2.5 \%-5 \%$ total biomass. For spawner production, the survival and growth rates were observed including immune response (immune gene expression).

\section{General Response of Immunity}

The Immune response was done by a challenge test with WSSV. The WSSV infected $L$. vannamei shrimp $(14.0 \mathrm{~g} \pm 0.8 \mathrm{~g})$ were used to feed tested shrimp. Aquarium tank with size of $60 \times 40 \times 39.5 \mathrm{~cm}$, approximately capacity of $95 \mathrm{~L}$ seawater were used in the present trials. Each aquarium was stocked with 20 shrimps and in duplicated. Infected WSSV fresh shrimp were use as feed and fed to the shrimp once time a day ( $10 \mathrm{~g} /$ aquarium) and artificial diet was given twice a day based on probiotic treatments. The challenge test was done for 144 hours. The hemolymph was taken every 24 hours for observation of haemocyte and gene immunity expression. The analysis for gene immunity expressions was done using RTqPCR. The WSSV infection level was analyzed through PCR using WSSV (93 bp) primer.

\section{Hemocyte}

Hemolymph was collected from shrimp from ventral-sinus cavity using 25 gauge needle and $1-\mathrm{mL}$ syringe filled with anticoagulant solution. Anticoagulant solution, modified with K-199 solution (Itami et al., 1994) became KC-199 with the addition of $2.38 \mathrm{~g} / \mathrm{L}$ HEPES and $5 \%$ L-cystein. Total hemocyte cell was calculated based on cell number from hemolymph $(0.1 \mathrm{~mL})$ of challenged shrimp in anticoagulant KC- 199 solution with amount of $0.4 \mathrm{~mL}$, by using a hemocytometer under light microscope with 400x magnification.

\section{Immune-related Gene Expression}

\section{Isolation of Total RNA and cDNA Synthesis}

Hemolymph was taken using a $25-\mathrm{G}$ needle with $1-\mathrm{mL}$ syringe containing $0.3 \mathrm{~mL}$ of cold anticoagulant solution ( $2 \% \mathrm{NaCl}$., $0.1 \mathrm{M}$ glucose, $30 \mathrm{mM}$ Na citrate, $26 \mathrm{mM}$ citrate acid, $10 \mathrm{mM}$ EDTA), then mixed and centrifuged at 12,000 $\mathrm{rpm}, 4^{\circ} \mathrm{C}$ for 15 minutes. Hemocyte pellets obtained were washed with cold anticoagulant solution. Furthermore, total RNA extraction was done using lysis solution with modified methods.
Synthesis of complementary DNA (cDNA) was performed using Ready-To-Go You-PRIME First Strand Beads (GE Healthcare, USA). The concentration of total RNA was as much as 3 $\mathrm{mg}$ in $30 \mathrm{~mL}$ DEPC, homogenized using a lowspeed vortex. Total RNA in microtube were incubated at $65^{\circ} \mathrm{C}$ for 10 minutes and subsequently transferred into new microtube and incubated on ice for two minutes. RNA solution was transferred into the first strand reaction mix beads tube. Primary race vect dT3 oligo (5'-gta ata cga ggg cac ata ata act tcg acg gcc TGG GCG GCT CGG ggt ttt ttt ttt ttt ttt t-'3) was used to synthesize cDNA (concentration of 100 pico mole) and added as much as of $3 \mathrm{~mL}$ into the reaction and left to stand for 1 minute. Microtube was incubated at $37^{\circ} \mathrm{C}$ for 1 hour.

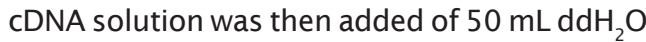
and stored at $-20^{\circ} \mathrm{C}$ for further analysis.

\section{RT-qPCR Analysis of the Immune Gene of L. vannamei After WSSV Challenge Test}

The analysis of transcriptional expression profiles of immune-related genes after challenge with WSSV were using RT-qPCR with specific primers following Wang et al. (2010), as indicated in Table 1.

RT-qPCR was performed using the ABI PRISM 7500 detection system sequences with $5 x$ Hot Firepol Evagreen qPCR mix (ROX). cDNA amplification reaction volume was $20 \mathrm{~mL}$ as the final concentration of $1 \mathrm{x}$ hot master mix (Rox); Primary F/R, 10 pmole of each $250 \mathrm{mM}$; $\mathrm{ddH}_{2} \mathrm{O}$ was added up to volume of $20 \mathrm{~mL}$ and cDNA (0.01 ng/uL). Conditions of thermal cycling for RT-q PCR were consisted of initial denaturation temperature of $95^{\circ} \mathrm{C}$ ( 15 minutes) followed by $95^{\circ} \mathrm{C}$ ( 15 seconds) and annealing temperature of $60^{\circ} \mathrm{C}$ ( 30 seconds) by 40 cycles and a final extension at $60^{\circ} \mathrm{C}$ for one minute. Calculation of $\triangle \mathrm{Ct}$ from PCR cycle threshold (Ct) gene were tested and then normalized relative to $\mathrm{Ct}$ 18 sRNA on the same sample. $\Delta \Delta \mathrm{Ct}$ values calculated from $\Delta \mathrm{Ct}$ (sample group tested challenged) - $\Delta \mathrm{Ct}$ (basic expressions, example exposure to 0 hours). Relative representation of different multiples of basic expression can be calculated by $2^{-\Delta \Delta \mathrm{ct}}$.

\section{RESULT AND DISSCUSSION}

\section{Probiotic Characteristic}

PCR amplification with universal primer $27 \mathrm{f}$ and $1492 \mathrm{r}$ on sequence 16 SrDNA indicated that amplification result was stable at 1,400 bp 
Table 1. Sequence primers used for the analysis of immune L. vannamei related genes by RTqPCR

\begin{tabular}{|c|c|c|c|c|c|}
\hline Immune system & Target gen & Name & Primer & Sequence (5"-3") & Gen Bank \\
\hline \multirow{2}{*}{$\begin{array}{l}\text { proPO activating } \\
\text { system }\end{array}$} & \multirow[t]{2}{*}{ Prophenoloxidase } & \multirow[t]{2}{*}{ proPO } & \multirow[t]{2}{*}{ proPO-F/R } & F:GAGATCGCAAGGGAGAACTG & \multirow[t]{2}{*}{ EF 565469} \\
\hline & & & & R:CGTCAGTGAAGTCGACACCA & \\
\hline \multirow[t]{2}{*}{ Clotting System } & \multirow[t]{2}{*}{ Transglutaminase } & \multirow[t]{2}{*}{ Tgase } & \multirow[t]{2}{*}{ Tgase-F/R } & F:СCTCAGGATCTCCTTCACCA & \multirow[t]{2}{*}{ EE 572305} \\
\hline & & & & R:TTGGGAAAACCTTCATTTCG & \\
\hline \multirow{10}{*}{$\begin{array}{l}\text { Antimic robial } \\
\text { peptide system }\end{array}$} & \multirow[t]{2}{*}{ Clotting protein } & \multirow[t]{2}{*}{$\mathrm{CP}$} & \multirow[t]{2}{*}{$\mathrm{CP}-\mathrm{F} / \mathrm{R}$} & F:TCTTTGCGCAGTTGGTGATC & \multirow[t]{2}{*}{ DQ984182 } \\
\hline & & & & R:TGAGGTGACCGAGTGCAAAA & \\
\hline & \multirow[t]{2}{*}{ Anti-LPS factor } & \multirow[t]{2}{*}{ ALF } & \multirow[t]{2}{*}{ ALF-F/R } & F:CTGTGGAGGAACGAGGAGAC & \multirow[t]{2}{*}{ DQ 208705} \\
\hline & & & & R:CCACCGCTTAGCATCTTGTT & \\
\hline & \multirow{2}{*}{ Crustin } & \multirow[t]{2}{*}{ Crustin } & \multirow[t]{2}{*}{ Crustin-F/R } & F:GAGGGTCAAGCCTACTGCTG & \multirow[t]{2}{*}{ AY 488497} \\
\hline & & & & R:ACTTATCGAGGCCAGCACAC & \\
\hline & \multirow{2}{*}{ Lysozyme } & \multirow{2}{*}{ Lyz } & \multirow{2}{*}{ lyz-F/R } & F:GAAGCGACTACGGCAAGAAC & \multirow[t]{2}{*}{ AF 425673} \\
\hline & & & & R:AACCGTGAGACCACCACTCT & \\
\hline & \multirow[t]{2}{*}{ Penaeiedin2 } & \multirow[t]{2}{*}{ PEN2 } & \multirow[t]{2}{*}{ PEN2-F/R } & F:TCGTGGTСTGССТGGTCTT & \multirow[t]{2}{*}{ Y 14925} \\
\hline & & & & R:CAGGTCTGAACGGTGGTCTTC & \\
\hline \multirow{4}{*}{$\begin{array}{l}\text { Antioxidant } \\
\text { defense } \\
\text { mechanism }\end{array}$} & \multirow{2}{*}{$\begin{array}{l}\text { Superoxdase } \\
\text { dismutase }\end{array}$} & \multirow[t]{2}{*}{ SOD } & \multirow[t]{2}{*}{ SOD-F/R } & F:ATCCACCACACAAAGCATCA & \multirow[t]{2}{*}{ DQ 005531} \\
\hline & & & & R:AGCTCTCGTCAATGGCTTGT & \\
\hline & Glutathione & GPx & GPO-F/R & F:TTTTCCGTGCAAAAAGGAC & AY 973252 \\
\hline & peroxidase & & & R:TAATACGCGATGCCCCTAAC & \\
\hline Internal control & 18s RNA & $18 \mathrm{~s}$ & $18 s-F / R$ & F:AGCAGGCTGGTTITTCCTTA & AF 186250 \\
\hline & & & & R:AGCAGGCTGGTITTTGCTTA & \\
\hline
\end{tabular}

molecule weight. By using 10 colonies sample replications of the same probiotic bacteria, after being analyzed through sequence the result was identified as Bacillus cereus BC at $99 \%$ similarity (KF234448.1) as shown in Table 2. According to DNA barcode, the identical value must be $97 \%-99 \%$ to confirm that the microorganism is identified as same species. The result of sequencing after alligment with BLAST showed $99 \%$ similarity meaning that Bacillus sp. $\mathrm{BC}$ probiotic that were being used in the production was confirmed as Bacillus cereus BC.

\section{Survival and Fry Production of $L$. vannamei Shrimp}

The observation on survival rate of L. vannamei shrimp larvae up to PL-1 stage showed no significant differences among three probiotic treatments, with values of $68.0 \%$ (Alteromonas sp. BY-9), $61.0 \%$ (Bacillus cereus, BC) and $70.0 \%$ (Alteromonas sp. BY-9 and Bacillus cereus $\mathrm{BC}$ ) respectively, while survival rate of control showed lower value (58.0\%). The survival rate pattern of larvae in each treatment is

Table 2. Similarity sequence of total DNA nucleotide of bacteria as probiotic in GenBank with same accession number

\begin{tabular}{|c|c|c|c|c|c|c|}
\hline \multirow{2}{*}{ Accession } & \multirow{2}{*}{ Description } & \multicolumn{2}{|c|}{ Score } & \multirow{2}{*}{$\begin{array}{c}\text { Query } \\
\text { coverage }\end{array}$} & \multirow{2}{*}{$\begin{array}{c}E \\
\text { value }\end{array}$} & \multirow{2}{*}{$\begin{array}{l}\text { Maximal } \\
\text { ident ity }\end{array}$} \\
\hline & & Maximal & Total & & & \\
\hline KF234448.1 & $\begin{array}{l}\text { Bacillus cereus strain JF9 } \\
16 \mathrm{~S} \text { ribosomal RNA gene } \\
\text { partial sequence }\end{array}$ & 1,757 & 1,757 & $82 \%$ & 0.0 & $99 \%$ \\
\hline
\end{tabular}




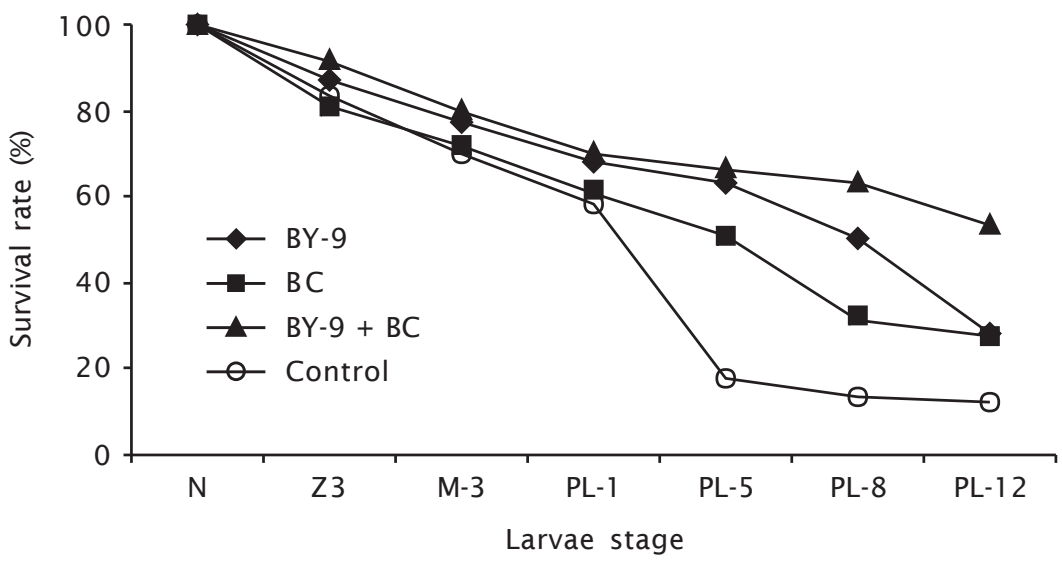

Figure 1. Survival rate of $L$. vannamei fry reared using various probiotics

presented in Figure 1. Furthermore, L. vannamei fry observed from PL-8 stage showed sharp decline of survival rate (31.03\%) on $\mathrm{Ba}$ cillus cereus $\mathrm{BC}$ probiotic treatment, while harvested fry in the same treatment of PL-12 the survival rate was only $27.58 \%$. The same condition occured on the use in Alteromonas sp. BY-9 probiotic showing significant decline in PL-12 (28.10\%) although survival at PL-8 was as high as $50.09 \%$.

The use of combined Alteromonas sp. BY9 and Bacillus cereus BC on fry production showed that the survival rates in PL- 8 and PL12 were $63.16 \%$ and $53.46 \%$, respectively. The survival rate of control was relatively low, starting from PL-8, at $13.45 \%$ and $12.48 \%$ for PL- 12 . From three probiotic treatments, the mortality occured gradually during rearing period from nauplii to PL-1, while in control the mortality was high from initial rearing until PL-5 stage.

Fry production of each treatment is presented in Table 3. The mortality of L. vannamei fry was due to Vibrio infection $\left(3-5 \times 10^{3} \mathrm{cfu} /\right.$ $\mathrm{mL}$ ) and cross contamination beetwen tank and stress due to the changes of environment from indoor to outdoor tanks.

Total production of PL- 8 fries using probiotic was 1,696,458 fry. The combined probiotic treatment of Alteromonas sp. BY-9 and Bacillus cereus BC produced 696,995 of fry. While application of single probiotic Alteromonas sp. BY- 9 or Bacillus cereus BC resulted a number of fries 516,925 and 348,798 fries respectively. In control, it only produced 133,740 fry. Nevertheless, after further rearing until PL-12, the number of fry decreased drastically due to continuous mortality. The remaining number of fry was 1,314,050 fry. The remaining fry from combined probiotic treatment was still relatively high (590,000 fry) (Table 3).

Decreasing number of shrimp fry were caused by mortality due to high density of fry in PL-8 and were already enough size for culturing in pond.

Table 3. Production and survival rate of L. vannamei reared with various of probiotics

\begin{tabular}{lcccc}
\hline \multicolumn{1}{c}{ Treat ment s } & $\begin{array}{c}\text { Number of fry } \\
\text { PL-8 st age }\end{array}$ & $\begin{array}{c}\text { Survival rate } \\
\text { (\%) }\end{array}$ & $\begin{array}{c}\text { Number of fry } \\
\text { PL-12 stage }\end{array}$ & $\begin{array}{c}\text { Survival rate } \\
\text { (\%) }\end{array}$ \\
\hline Control & 133,740 & 13.45 & 124,050 & 12.48 \\
Bacillus cereus BC & 348,798 & 31.03 & 310,000 & 27.58 \\
Alteromonas sp. BY-9 & 516,925 & 50.09 & 290,000 & 28.10 \\
Alteromonas sp. BY-9 and & 696,995 & 63.16 & 590,000 & 53.46 \\
Bacillus cereus BC & & & $\mathbf{1 , 3 1 4 , 0 5 0}$ & \\
\hline Total number of fry & $\mathbf{1 , 6 9 6 , 4 5 8}$ & &
\end{tabular}


L. vannamei fry of PL-12 were then treated with Bacillus cereus BC and Alteromonas sp. BY-9 and combined probiotic. It was selected 80,000 fry (15\%-25\%) from each present population, while in control treatment, all fry were cultured due to high mortality. The objective of rearing the fry until PL-29 (Table 4) was to obtained shrimp spawners from the fry which were having faster growth through selection.

At low density per tank (volume $40 \mathrm{~m}^{3}$ ), achieved survival rate up to PL-29 was high enough (78.63\%-91.35\%) while survival rate of shrimp fry in control was only $53.86 \%$. It can be understood that the space or living area might be better and there was no space competition on wall surface to stick amounts of shrimp fry. While in the control, the mortality was due to Vibrio infection $\left(3-5 \times 10^{3} \mathrm{cfu} / \mathrm{mL}\right)$. Vibrio infection occured in control treatment since PL-29. It seemed that body defense were developed just to avoid infection in control treatment since there was no probiotic addition during the rearing. This was related with protection mechanism of fry until spawners of L. vannamei shrimp to disease infection. One functions of probiotic is to stimulate the non spesific immunity mechanism and to protect the shrimp from pathogen microorganism infection.

Selection of L. vannamei in PL-29 stadia was held to find big size fry (grow faster) and the density of fry in PL-29 has to be adjusted with rearing tank to become volume $8 \mathrm{~m}^{3}$. The initial density of fry for spawner production is presented in Table 5.

\section{The Survival and Growth of $L$.} vannamei Shrimp Spawners

The survival rate of spawners of L. vannamei showed that after three times of selection, the number of $L$. vannamei is higher in probiotic treatment compared to control (Table 5). The mortality was mostly caused by canibalism especially during moulting period.

The growths of both length and weight of fries up to adult as spawner size showed that no significant differences between treatments $(P>0.05)$ as shown in Figure 2. Shrimp spawners weight in probiotic treatment of Bacillus cereus BC, Alteromonas sp. BY-9 and combina-

Table 4. Survival rate of L. vannamei shrimp from PL-12 to PL-29 reared with various of probiotics

\begin{tabular}{|c|c|c|c|}
\hline \multirow{2}{*}{ Treat ments } & \multicolumn{2}{|c|}{ Number of fry } & \multirow{2}{*}{$\begin{array}{c}\text { Survival } \\
\text { rate } \\
\text { (\%) }\end{array}$} \\
\hline & PL-12 st age & PL-29 st age & \\
\hline Control & 124,050 & 66,816 & 53.86 \\
\hline Bacillus cereus BC & 80,000 & 62,900 & 78.63 \\
\hline Alteromonas sp. BY-9 & 80,000 & 67,907 & 84.88 \\
\hline $\begin{array}{l}\text { Bacillus cereus } \mathrm{BC} \text { and } \\
\text { Alteromonas sp. BY-9 }\end{array}$ & 80,000 & 73,080 & 91.35 \\
\hline
\end{tabular}

Table 5. Survival rate of L. vannamei spawner reared with various of probiotics

\begin{tabular}{|c|c|c|c|c|c|}
\hline \multirow[b]{2}{*}{ Treat ments } & \multirow{2}{*}{$\begin{array}{c}\text { PL-75 } \\
1^{\text {st }} \\
\text { selection } \\
\text { (pcs) }\end{array}$} & \multicolumn{2}{|c|}{ PL-255 } & \multicolumn{2}{|c|}{ PL-285 } \\
\hline & & $\begin{array}{l}2^{\text {nd }} \\
\text { selection } \\
\quad(p c s)\end{array}$ & $\begin{array}{c}\text { Survival } \\
\text { rate } \\
\text { (\%) }\end{array}$ & $\begin{array}{l}3^{\text {rd }} \\
\text { selection } \\
(p c s)\end{array}$ & $\begin{array}{c}\text { Survival } \\
\text { rate } \\
(\%)\end{array}$ \\
\hline Control & 1,766 & 861 & 48.75 & 550 & 63.88 \\
\hline Bacillus cereus BC & 1,337 & 1,063 & 78.76 & 876 & 83.19 \\
\hline Alteromonas sp. BY-9 & 1,589 & 873 & 54.94 & 792 & 90.72 \\
\hline $\begin{array}{l}\text { Alteromonas sp. BY-9 and } \\
\text { Bacillus cereus BC }\end{array}$ & 1,458 & 607 & 41.63 & 518 & 85.34 \\
\hline
\end{tabular}



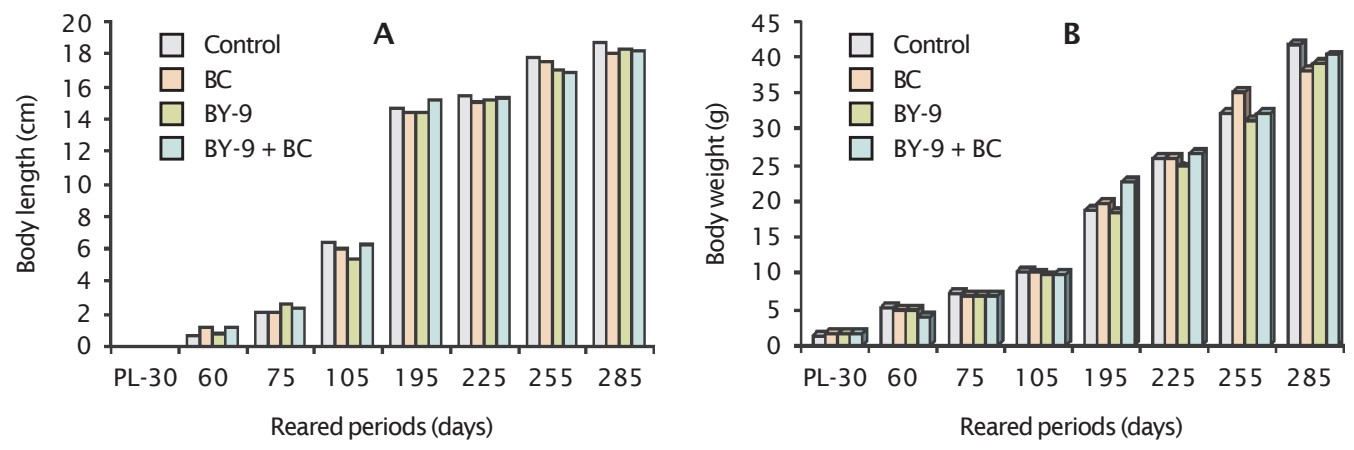

Figure 2. Body length (A) and body weight (B) of L. vannamei shrimp reared with various of probiotics

tion of both were $37.91 ; 38.96$; and $40.02 \mathrm{~g}$, respectively, while in control treatment was $41.57 \mathrm{~g}$. The similar result also occured on the growth in length. This condition seemed to be related with the unequal density of broodstock candidate. The survival rate was relatively low in control and therefore the growth was better compared to that of Alteromonas sp. BY-9 probiotic treatment.

\section{Immune Responses}

Challenge test with WSSV, where L. vannamei reared in combined probiotic (Alteromonas sp. BY-9 and Bacillus cereus BC) from larval stage to spawners, have shown that the survival rate was higher against WSSV infec- tion. In the single probiotic treatment, the mortality was not significantly different to the control. Lethal dose-50 (LD-50) on this challenge test occurred 72 hours post exposure (Table $6)$.

Mortality of L. vannamei shrimp spawner which were caused by WSSV infection had a positive correlation with PCR test results using spesific primer (93 bp). Shrimp spawners with combined probiotic (Alteromonas sp. BY9 and Bacillus cereus BC) survived more against virus infection compared to that at either single probiotic treatment or control. The role of Alteromonas sp. BY-9 is to suppress the incident of Vibrio infection during larval rearing (biological control). While Bacillus cereus BC is

Table 6. LD-50 of L. vannamei shrimp after challenge test with WSSV at 72 hours exposure time

\begin{tabular}{|c|c|c|c|c|c|c|c|c|}
\hline \multirow{2}{*}{$\begin{array}{l}\text { Exposure time } \\
\text { (hours) }\end{array}$} & \multicolumn{8}{|c|}{ Fry mortality (pcs) in probiotic treatment } \\
\hline & $\mathrm{C}-1$ & C-2 & BC-1 & BC-2 & BY-1 & BY -2 & BY -BC-1 & BY -BC-2 \\
\hline 0 & - & - & - & - & - & - & - & - \\
\hline 24 & - & - & - & - & 6 & 1 & 1 & 1 \\
\hline 48 & 3 & 4 & 1 & 2 & 2 & 2 & - & 1 \\
\hline 72 & 11 & 6 & 12 & 10 & 7 & 6 & 2 & 1 \\
\hline LD-50 & 14 & 10 & 13 & 12 & 15 & 9 & 3 & 3 \\
\hline Average & \multicolumn{2}{|c|}{12} & \multicolumn{2}{|c|}{12.5} & \multicolumn{2}{|c|}{12} & \multicolumn{2}{|c|}{3} \\
\hline 96 & - & 3 & 3 & 4 & - & 4 & 7 & 3 \\
\hline 120 & - & - & - & - & 1 & - & 3 & 6 \\
\hline 144 & - & - & - & - & - & - & 1 & 2 \\
\hline $\begin{array}{l}\text { Total number of } \\
\text { fry mortality }\end{array}$ & 14 & 13 & 16 & 16 & 16 & 13 & 14 & 14 \\
\hline
\end{tabular}


probiotic which help the digestion system of shrimp. The combined role of both probiotics was to protected shrimp spawners from disease infection and resulted in higher survival rate against WSSV virus exposure.

The result of observation on hemocyte number of L. vannamei shrimp with probiotic at initial treatment (before WSSV exposure) was 420-530,5 x $10^{4}$ cells $/ \mathrm{mL}$ (Table 7). Nevertheless, after exposure with WSSV, it can be seen that the addition of combined probiotic of Alteromonas sp. BY-9 and Bacillus cereus BC decreased to $391.75 \times 10^{4}$ cells $/ \mathrm{mL}$ after 72 hours post exposure. The number of hemocyte by addition of single probiotic (Alteromonas sp. BY-9) were $402.5 \times 10^{4}$ cells $/ \mathrm{mL}$ and 432.5 $\times 10^{4}$ cells $/ \mathrm{mL}$ (Bacillus sp. BC), while in control the number was relatively low $\left(229 \times 10^{4}\right.$ cells $/ \mathrm{mL}$ ). This phenomenon could be explained that hemocyte is a system for body immune defense of shrimp. The incidence of WSSV infection in internal cell would disturb the metabolism and hemocyte production.

In crustaceans, haemocytes involve in the reaction called immediate defense reaction i.e. modulation, encapsulation, and phagocytic (Bachere, 2000) The cell circulation has implication to different immune responses such as melanisation and coagulation mediated by releasing haemocytes effector such as prophenoloxidase (pro PO), activating system, transglutaminase or anti bicobial peptide. Beside that, immune-related protein on shrimp could be illustrated like clotting protein, lysozyme, Lipo Poly Saccahride aglutinin, and $\beta$-glucanbinding protein. Process of activation system of ProPO needs protease activation and this action requires control precision to avoid tissue damage. Phenoloxydase is produced from prophenoloxidase (proPO system) activation as "cascade" phenomenon with several steps for organ function performance.

Body immune mechanism of shrimp differs to fish due to immunoglobulin. Immunoglobulin of shrimp is known as Prophenoloxidase Activating Enzyme (PPA) (Lee \& Soderhall, 2002). PPA is a protein located in hemocyte granular and could be activated by Lipopolysacharide (LPS) and $\beta$ 1,3-Glucan that promoted the change of prophenoloxidase into phenoloxidase. The impact of this change will produce a type of protein called Opsonin Factor that could induce agranuler hematocyte cell to carry out phagocytosis process. Hemocyte cell is also degranulated and some protein will be released as well as an immune response (Van de Braak, 2002).

\section{Immunity Gene Expression}

\section{Pro PO Activating System}

Testing for immunity gene expression using RT-qPCR on L. vannamei shrimp spawners was aimed to study gene transcription arrangement during WSSV infection. The expression level of mRNA gene as individual of shrimp spawners was normalized using 18s rRNA as an endogenous reference and then expressed to basic expression in 0 hour exposure. The results is presented in each immune or defense mechanism arrangement in the shrimp.

Activation gene system of proPO (prophenoloxidase) can be seen significantly increasing the regulation on the addition of probiotic combination (Alteromonas sp. BY-9 and Bacillus cereus BC) from 24 to 72 hrs after exposure test. Transcriptional level of proPO reached 1.6-2.0 times bigger than control. While the

Table 7. Total number of hemocytes cell of L. vannamei shrimp reared with various of probiotics after challenge tested with WSSV

\begin{tabular}{lcccc}
\hline \multirow{2}{*}{\multicolumn{1}{c}{ Treat ment s }} & \multicolumn{4}{c}{$\begin{array}{c}\text { Number of hemocytes (x 10,000 cell/mL) } \\
\text { exposure time (hours) }\end{array}$} \\
\cline { 2 - 5 } & $\mathbf{0}$ & $\mathbf{2 4}$ & $\mathbf{4 8}$ & $\mathbf{7 2}$ \\
\hline Control & 397.5 & 299.5 & 229 & 229 \\
Bacillus cereus BC & 487.5 & 768.75 & 432.5 & 432.5 \\
Alteromonas sp. BY-9 & 530.5 & 302 & 116 & 402.5 \\
$\begin{array}{l}\text { Alteromonas sp. BY-9 and } \\
\text { Bacillus cereus BC }\end{array}$ & 420 & 365.5 & 391.75 & 391.75 \\
\hline
\end{tabular}


addition of Bacillus cereus BC can be seen only on 72 hrs after WSSV exposured test and reached 2 times bigger than that at control (Figure 3).

Activation system of proPO in shrimp is important aspect of innate immunity, and innitial step in catalized melanisation on invertebrata. Wang et al. (2010) stated that expression level of proPO increased on Fenneropenaeus chinensis that infected by Vibrio anguillarum. Regulation increasement of proPO is important role as a response against WSSV infection.

Immune system of shrimp, as well as in other invertebrates, depended on innate immunity. Innate immunity is devided in humoral defense (activate of some parts of proteolytic like prophenoloxidase/proPO system, clotting hemolymp mechanism, melanisation response immune antimicroba) and cellular defense (fagositosis, encapsulasion, cellular degranulasion, and releasing defense factors). Innate immunity in invertebrata is mediated by circular hemocyte.

\section{Hemolymph Clotting Mechanism}

Transglutaminase (Tgase) and clotting protein (CP) acts in shrimp clotting system. Expression level of Tgase gene in the addition of combined probiotic treatment was significantly higher compared to control after 48 hours infected by WSSV. The same response on the addition of Bacillus cereus BC probiotic from 24 until 72 hours exposured to WSSV showed significant different to control.

$\mathrm{CP}$ gene expression increasing arrangement from 24 to 72 hours after exposured by WSSV in combined probiotic (Figure 4). In the injured shrimp, clotting system acts soon to

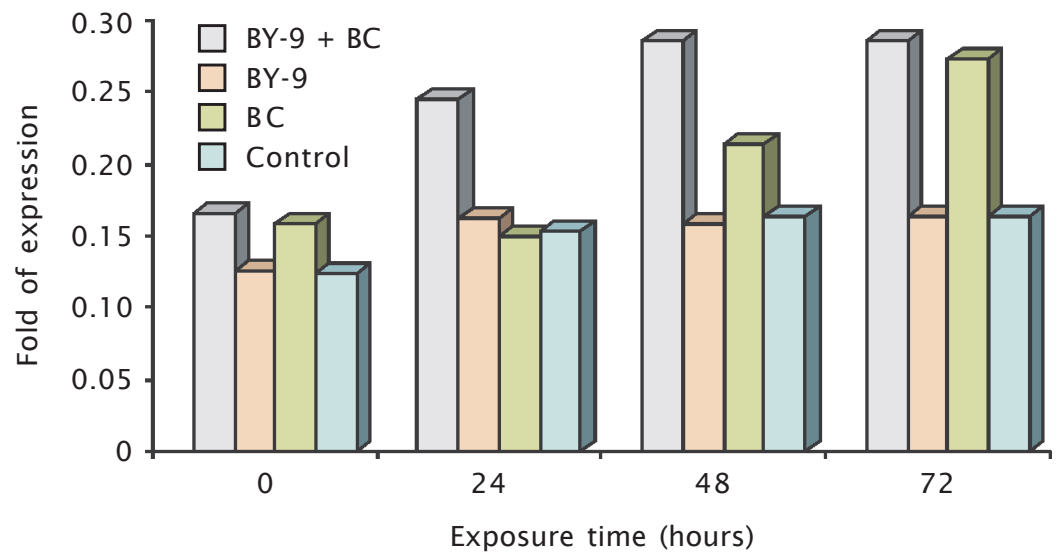

Figure 3. Quantitative relative mRNA of proPO in L. vannamei hemocytes after WSSV challenge test
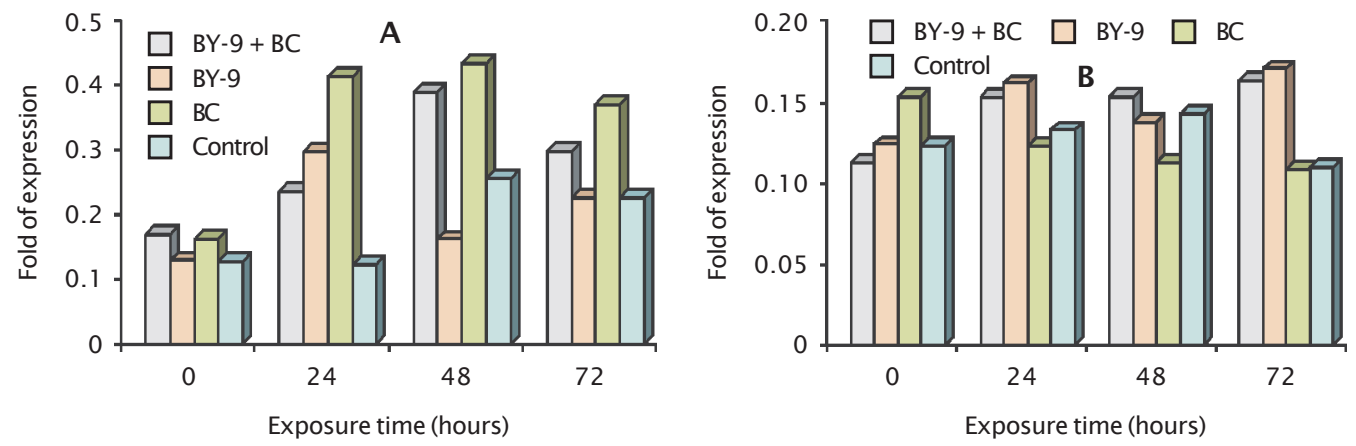

Figure 4. Quantitative relative mRNA of Transglutaminase (Tgase) (A) and Clotting Protein (CP) (B) in L. vannamei hemocytes after WSSV challenge test 
prevent hemolymp lost. Clotting system is also involved in mobilization to avoid spreating pathogen through hemocoel. While on transglutaminase (Tgase) has a role in mediating hemolymph coagulation by trigerred clotting polymerisation protein. The use of interferens RNA showed that Tgase and CP has a role in maintaining and avoiding bacteria ( $V$. penaecida) and virus (WSSV) in P. japonicus shrimp (Maningas et al., 2008).

\section{Antimicrobial Peptide System}

Expression of four kinds of peptide antimicrobial gene has been observed such as Crustin, Anti-lipopolysaccharide factors (ALF), Penaeidin2 (PEN2), and Lysozyme (Lyz). As seen in Figure 5 and 6, the Crustin and Lyzosyme indicated that the peak of expression was relatively high, after $24-48$ hours and $48-72$ hours after exposure test to WSSV in combined probiotic treatment, while the highest ALF was at 48 hours and it was significantly different compared to control treatment. The highest
PEN2 gene expression was found in the addition of Bacillus cereus BC at 24 hours after challenge test to WSSV, while in other treatments, the PEN2 has no participation on immunity response. The different expressions of Crustin, ALF, PEN2, and Lyz had no significant differences in shrimp spawners given Alteromonas sp. BY-9 probiotic.

Antimicrobial peptide (AMPs) has been characterized and present in all living microorganisms. The group of AMPs consist of anti-lipopolysaccharide factors (ALF) protein. ALF is a small part of basic protein and has a role to neutralize lipopolysaccharide (LPS). Another role of ALF is involved in inhibition of fungi infection and viral replication or the growth of virus (Wang et al., 2010).

Crustin is a unique compound in crustacea and dominantly consists of cysteine-region and WAP (whey acidic protein). In P. monodon, transcription level of Crustin-like antimicrobial peptide (Crus-likePm) increased after exposure test with $V$. harveyi through injection.
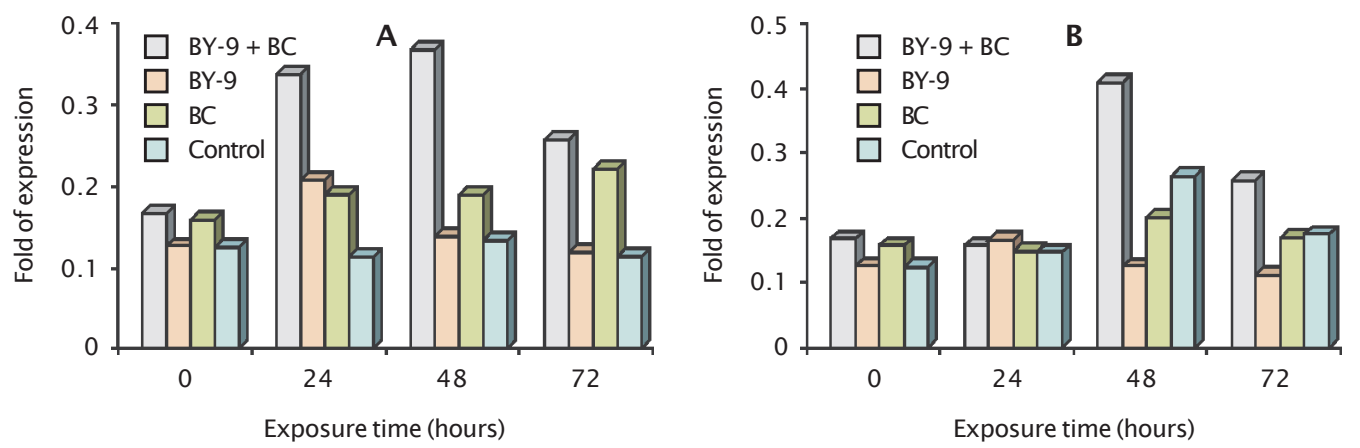

Figure 5. Quantitative relative mRNA of Crustin (A) and Anti-Lipopolysaccharide Factor (ALF) (B) in L. vannamei hemocytes after WSSV challenge test
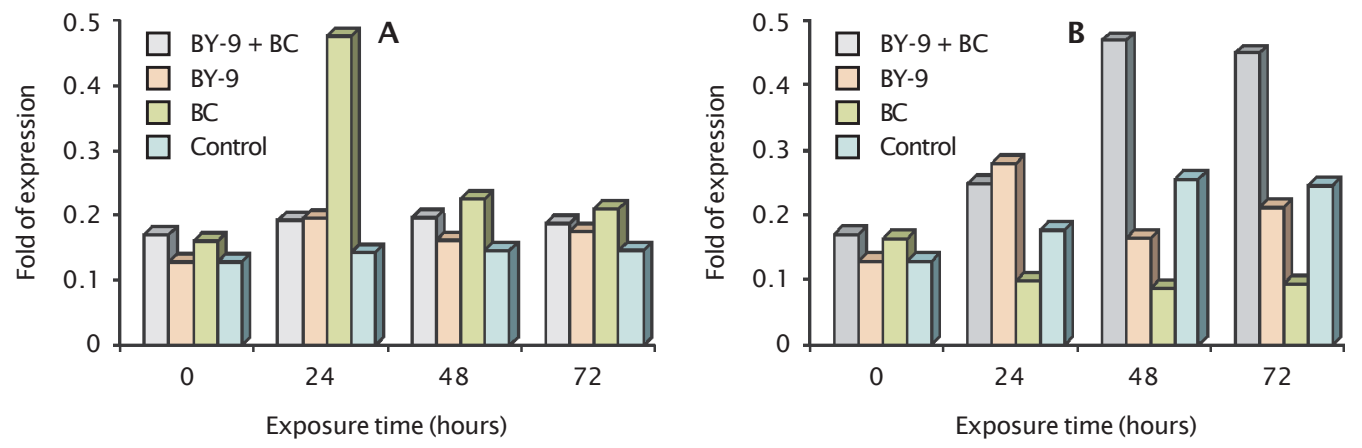

Figure 6. Quantitative relative mRNA value of Penaiedin (PEN2) (A) and Lysozyme (Lyz) (B) in $L$. vannamei hemocytes after WSSV challenge test 

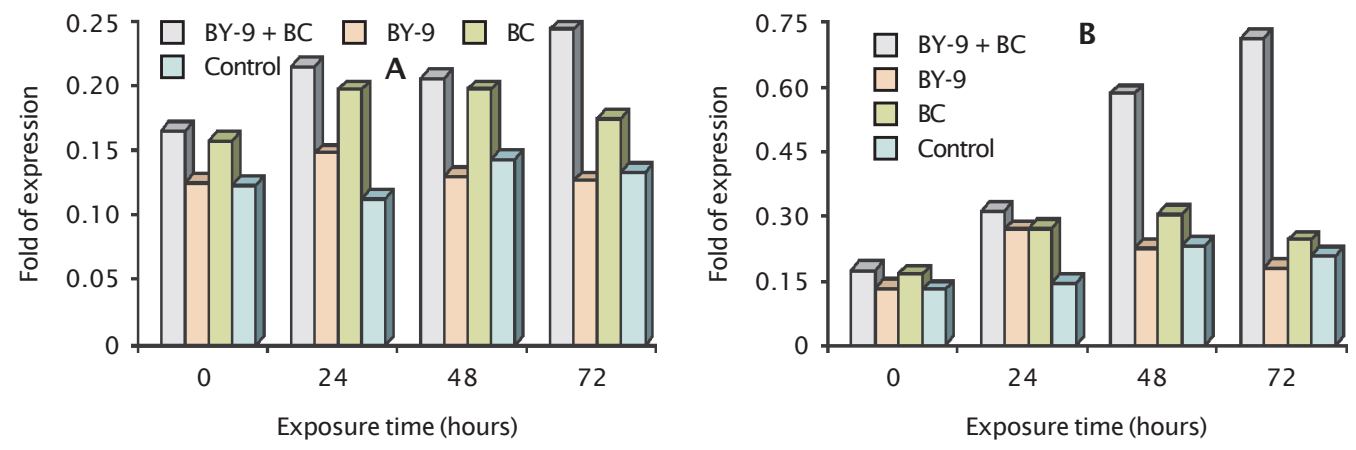

Figure 7. Quantitative relative mRNA value of Superoxidase dismutase (SOD) A) and Glutathione peroxidase (GPX) (B) in L. vannamei hemocytes after WSSV challenge test

Lysozyme also a innate immune molecule in eukaryot and could hydrolized beta $(1,4)$ glycosidic linked with peptidoglycan and caused the disturbance of bacteria cell wall and fungi. Lysozyme is an important component on defence system of the shrimp in anti bacteria Gram negative.

Penaeidins is also an Antimicrobial peptide (AMPs) only exsist in Penaeid shrimp i.e. Penaeidin2 (PEN2), Penaeidin3 (PEN3), and Penaeidin4 (PEN4) that could be distinguished from amino acids sequences. Penaeidins were very effective to counter gram-positive bacteria.

\section{Antioxidant Defense Mechanism}

Superoxidase dismutase (SOD) and Glutathione peroxidase (GPx) are the antioxidant enzymes mediating the oxydative injury. The highest expression level of SOD in shrimp with addition of probiotic combination was 1.8-2.0 times (24-72 hours) after WSSV test compared to control. The expression level of GPX was obtained at 48-72 hours after WSSV test in the treatment with combined probiotic (Figure 7).

In invertebrate hemocyte, antimicrobacterial activity was the derivative of oxygen species reactive (ROS) during and after phagocytosis. ROS product could also cause disease pathogenesis. As antioxidant enzyme, SOD has a role of a first eliminator on ROS and converted into hydrogenperoxyde and oxygen, while GPx transformed hydrogenperoxyde into water and oxygen by catalyzation before hydroxyl radical could be produced. When the shrimp is infected by the disease, the oxydative stress will occur.
The response of shrimp immune-related gene to WSSV will help to explain the regulatory of shrimp host immune againts viral infection. The use of RT-q PCR for changing characterisation of mRNA expression from nine immune related genes after challenge test with WSSV will give a clear function on the possibility implication of probiotic.

\section{CONCLUSIONS}

The application of probiotics to improve immunity in fry and spawner production of $L$. vannamei has been proven by the results of the immune gene expression analysis. Production at PL-12 of L. vannamei treated with combined probiotics (Alteromonas sp. BY-9 and Bacillus cereus $\mathrm{BC}$ ) resulted in higher survivals (53.46\%) than other. Production of spawners in terms of survival and growth rates were comparable among probiotics treatments.

\section{ACKNOWLEGEMENT}

This research results supported by DIPA 2013 of Gondol Institute for Mariculture Research and Development, Ministry of Marine Affairs and Fisheries. We thanks to all technician belonged to Biotecnological laboratory member for their excellent help during the rearing periods.

\section{REFERENCES}

Balcazar, J.L., Rojas-Luna, T., \& Cunningham, D.P. (2007). Effect of the addition of four potential probiotic strains on the survival of pacific white shrimp (Litopenaeus vannamei) following immersion challenge with Vibrio parahaemolyticus. Journal of Invertebrate Pathology, 96, 147-150. 
Bachere, E. (2000). Shrimp immunity and disease control. Aquaculture, 191, 3-11.

Fu, L.L., Wang, Y., Wu, Z.C., \& Li, W.F. (2011). In vivo assesment for oral delivery of Bacillus subtilis harboring a viral protein (VP28) against white spot syndrome virus in Litopenaeus vannamei. Aquaculture, 322323, 33-38.

Gullian, M., Thompson, F., \& Rodriquez, J. (2004). Selection of probiotic bacteria and study of their immunostimulatory effect in Penaeus vannamei. Aquaculture, 233, 1-14.

Haryanti, Permana, G.N., Sembiring, S.B.M., \& Trimurtini, J. (2003). The use of Alteromonas sp. BY-9 bacteria preserved on fry production of black tiger shrimp Penaeus monodon. Indonesia Fisheries Research Journal, 9(2), 47-55 (In Indonesia).

Haryanti, Sugama, K., Tsumura, S., \& Nishijima, T. (2001). Enhance production of black tiger shrimp Penaeus monodon postlarvae by probiotic bacterium Alteromonas sp. Indonesian Fisheries Research Journal, 7(1), 1-6.

Itami, T., Takahashi, Y., Tsuchihira. E., Igusa, H. \& Kondo, M. (1994). Enhancement of disease resistance of kuruma prawn Penaeus japonicus and increase in phagocytic activity of prawnhemocyte after oral administration of betta-1.3-glucan (schizophyllan) in chou et al. (Eds.). Proceeding of third Asian Fisheries Forum. The Asian Fisheries Society, Manila, Philippines. p. 375-378.

Jimenez-Vega, F., Yepiz-Plascencia, G., Soderhall, K., \& Vargas-Albores, F. (2004). A single WAP domain-containing protein from Litopenaeus vannamei hemocytes. Biomedical and Biophisical Research Communication, 314, 681-687.

Karla, Y., Leyva-Madrigal, Luna-Gonzalez, A., Escobedo-Bonilla, C.M., Yesus, A., FierroCoronado, \& Maldonado-Mendoza, I.E. (2011). Screening for potential probiotic bacteria to reduce prevalence of WSSV and IHHNV in white shrimp (Litopenaeus vannamei) under experimental condition. Aquaculture, 322-323, 16-22.

Lee, S-Y., \& Soderhall, K. (2002). Early events in crustacean innate immunity. Fish \& Shellfish Immunology, 12, 42 1-437.

Li, J., Tan, B., \& Mai, K. (2009). Dietary probiotic Bacillus OJ and isomaltooligosaccharides influence the intestine microbial populations, immune response and resistance to white spot syndrome virus in shrimp ( $\mathrm{Li}$ - topenaeus vannamei). Aquaculture, 291, 35-40.

Liu, K-F., Chiu, C-H., Shiu, Y-L., Cheng, W., \& Liu, C-H. (2010). Effects of the probiotic, Bacillus subtilis $\mathrm{E}-20$, on the survival, development, stress tolerance, and immune status of white shrimp, (Litopenaeus vannamei) larvae. Fish \& Shellfish Immunology, 28, 837-844.

Luis-Villasenor, I.E., Macias-Rodriguez, M.E., Gomez-Gil, B., Ascencio-Valle, F., \& CampaCordova, A.I. (2011). Beneficial effect of four Bacillus strain on the larval cultivation of (Litopenaeus vannamei). Aquaculture, 321, 136-144.

Maningas, M.B., Kondo, H., Hirono, I. Saito-Taki, T., \& Aoki, T. (2008). Essential function of transglutaminase and clotting protein in shrimp immunity. Mol. Immunol., 45, 12691275.

Marine and Fisheries Statistic Book. (2012). Aquaculture Statistic 2012. Ministry of Marine Affairs and Fisheries. Jakarta. (in Indonesia).

Rodriquez, J., Espinosa, Y., Echeverria, F., Cardenas, G., Roman, R., \& Stern, S. (2007). Exposure to probiotics and $\beta-1,3 / 1,6$ glucans in larviculture modifies the immune response of Penaeus vannamei juveniles and both the survival to White Spot Syndrome Virus challenge and pond culture. Aquaculture, 273, 405-415.

Tseng, D-Y., Ho, P-L., Huang, S-Y., Cheng, S-C., Shiu, Y-L., Chiu, C-S., \& Liu, C-H. (2009). Enhancement of immunity and disease resistance in the white shrimp, Litopenaeus vannamei, by the probiotic, Bacillus subtilis E-20. Fish \& Shellfish Immunology, 26, 339344.

Van de Braak, K. (2002). Haemocytic defence in black tiger shrimp (Penaeus monodon). Disertation. van Wangeningen University. Netherlands, 168 pp.

Wang, H.C., Tseng, C.W., Lin, H.Y., Chen, I.T., Chen, Y.H., Chen, Y.M., Chen, T.Y., \& Yang, H.L. (2010). RNAi knock-down of the Litopenaeus vannamei Toll gene (LvToll) significantly increase mortality and reduces bacterial clearance alter challenge with Vibrio harveyi. Development and Comparative Immunology, 34, 49-58.

Zhou, X., Wang, Y., \& Li, W. (2009). Effect of probiotic on larvae shrimp (Penaeus vannamei) based on water quality, survival rate and digestive enzyme activities. Aquacul- 
ture, 287, 349-353.

Zokaeifar, H., Balcazar, J.L., Saad, C.R., Kamarudin, M.S., Sijam, K., Arshad, A., \& Nejat, N. (2012). Effects of Bacillus subtilis on the growth performance, digestive en- zymes, immune gen expression and diseases resistance of white shrimp, Litopenaeus vannamei. Fish \& Shellfish Immunology, 33, 683-689. 